\title{
ANALISIS PENGARUH TINGKAT KURS DAN SUKU BUNGA BANK INDONESIA DENGAN JUMLAH UANG BEREDAR, TERHADAP TINGKAT INFLASI DI INDONESIA
}

\author{
DWI PUSPITA AGUSTIN \\ adwipuspita783@gmail.com
}

\section{Jurusan Sistem Informasi Akuntansi Universitas Gunadarma}

\begin{abstract}
ABSTRAK
Penelitian ini membahas tentang "Analisis Pengaruh Suku Bunga Bi, Jumlah Uang Beredar dan Nilai Tukar Terhadap Tingkat Inflasi Di Indonesia Periode 2012-2020", bertujuan untuk mengetahui pengaruh BI Rate, Uang Beredar, dan Nilai Tukar Terhadap Inflasi di Indonesia dan menggunakan model koreksi kesalahan Engle-Granger (ECM-EG). Hasil penelitian ini menunjukkan bahwa BI Rate berpengaruh positif dan signifikan terhadap tingkat inflasi di Indonesia. Sedangkan jumlah uang beredar dan nilai tukar Rp/dolar AS berpengaruh positif dan tidak signifikan terhadap laju inflasi di Indonesia.

Kata Kunci : Tingkat Inflasi, Nilai Tukar, BI Rate dan Uang Beredar.
\end{abstract}

\section{ABSTRACT}

This study discusses the "Analysis of Effect of Bi Interest rates, Money Supply and Exchange Rate Against Inflation Rate In Indonesia Period 20122020 ", aims to determine the effect of BI Rate, Money Supply, and the Exchange Rate on Inflation in Indonesia and using the error correction model Engle-Granger (ECM-EG). The results of this study indicate that the BI Rate has a positive and significant effect on the inflation rate in Indonesia. Meanwhile, money supply and exchange rate Rp/Us dollar have a positive and not significant effect on the rate of inflation in Indonesia.

Keywords: Inflation Rate, Exchange Rate, BI Rate and Money Supply.

\section{PENDAHULUAN}

\section{Latar Belakang}

Perekonomian merupakan salah satu bidang yang senantiasa mendapatkan perhatian utama, sebab ketidakstabilan ekonomi yang terjadi dapat menimbulkan berbagai masalah yang berdampak luas pada masyarakat, seperti pertumbuhan ekonomi yang rendah di suatu wilayah yang mengakibatkan tingginya nilai inflasi, meningkatnya jumlah pengangguran serta ketidakstabilan harga barang-barang kebutuhan masyarakat.

Kondisi makro ekonomi secara negatif mempengaruhi pembangunan ekonomi secara keseluruhan. Inflasi yang tinggi dan bergejolak adalah hasil 
dari kenaikan harga barang dan jasa umum. Dan terus menerus untuk sementara waktu. Kenaikan harga tidak meningkatkan daya beli masyarakat, mereka tidak dapat menjual produk yang mereka hasilkan, dan produsen dapat merugi sehingga tidak meningkatkan investasi. Ketika jumlah investasi menurun, Pendapatan nasional yang menurun, mengindikasikan terjadinya keterlambatan dalam pertumbuhan ekonomi, jika tidak segera ditangani, hal ini tentu akan mengganggu stabilitas kegiatan ekonomi makro maupun mikro dan dapat menghambat percepatan pembangunan di segala bidang.

Untuk mengantisipasi terjadinya berbagai masalah ekonomi tersebut maka pemerintah mencanangkan berbagai kebijakan moneter seperti dengan jalan menetapkan Inflation Targeting Framework (ITF) pada tahun 2005. Penetapan ITF bertujuan untuk mempertahankan nilai inflasi agar tetap stabil dan mencegah kenaikannya. Arimurti dan Trisnanto (2011:6) ITF merupakan sejarah awal bagi penetapan berbagai kebijakan moneter untuk mengatasi berbagai permasalahan ekonomi yang terjadi pasca terjadinya krisis ekonomi Indonesia masa reformasi tahun 1998. Pada dasarnya, kerangka kebijakan moneter antara lain berbagai kebijakan yang dapat diaplikasikan dan diandalkan untuk menekan terjadinya inflasi.

Oleh karena itu, ITF diharapkan dapat menekan inflasi. Lihat Tabel 1.1 di bawah ini untuk melihat evolusi inflasi hingga tahun 2020 .

Tabel 1.1

Perkembangan Tingkat Inflasi di Indonesia Periode 2012 - 2020

\begin{tabular}{cc}
\hline Tahun & Inflasi (Persen) \\
\hline 2012 & 4.3 \\
2013 & 8.38 \\
2014 & 8.36 \\
2015 & 3.3 \\
2016 & 3.02 \\
2017 & 6.96 \\
2018 & 3.13 \\
2019 & 2.72 \\
2020 & 1.68 \\
\hline
\end{tabular}

Sumber: Badan Pusat Statistik 2020 
Tabel 1.1 menunjukkan adanya evolusi terhadap inflasi yang terjadi pada tahun 2012 sampai tahun 2020. Tabel memperlihatkan adanya fluktuasi dari tahun ke tahun. Inflasi ditunjukkan pada tahun 2013, di mana terjadi inflasi sebesar 8,38\%. Namun pada tahun 2014 sampai tahun 2016 inflasi mengalami penurunan. Tetapi sayangnya, laju inflasi kembali meningkat pada tahun 2017, hingga puncaknya pada tahun 2020 kembali menurun menjadi $1,68 \%$.

Terdapat berbagai faktor yang menyebabkan terjadinya inflasi di Indonesia. Salah satunya adalah perubahan tingkat suku bunga yang ditentukan oleh kebijakan Ban Indonesia, yang dalam istilah disebut BI Rate. BI Rate merupakan bagi bank untuk menetapkan tingkat suku bunga. Menurut pendapat Yodiatmaja (2012:3), rasio BI yang berubah akan diikuti dengan perubahan pada beberapa variabel makroekonomi yang pada akhirnya akan mempengaruhi tingkat inflasi. Rasio BI yang mengalami kenaikan akan menyebabkan tingkat suku bunga pinjaman dan deposito mengalami kenaikan sehingga masyarakat akan terdorong untuk menabungkan uangnya di bank, hal ini mengakibatkan terjadi pengurangan jumlah uang yang beredar di masyarakat. Akibat selanjutnya, para pelaku ekonomi akan mengurangi investasi karena terjadi kenaikan harga-harga.

Perekonomian yang didorong oleh lebih banyak keuangan cenderung menghasilkan harga yang lebih tinggi untuk barang-barang manufaktur dan inflasi yang lebih tinggi. Volatilitas nilai tukar rupiah mempengaruhi arus modal dan investasi, serta perdagangan internasional. Indonesia yang mengimpor bahan baku industri dalam jumlah besar berdampak signifikan terhadap volatilitas nilai tukar yang ada, yang dibuktikan dengan kenaikan biaya produksi barang dan jasa. Ketika nilai tukar rupiah jatuh, Jika nilai rupiah jatuh, maka kondisi perekonomian Indonesia tentu akan menjadi tidak stabil, terjadi krisis ekonomi yang nilai tukar rupiah terhadap mata uang asing menjadi semakin jatuh (Triyono, 2008: 156). Sementara itu, nilai tukar yang terus mengalami kenaikan juga membuat produsen kesulitan memperoleh bahan baku dan alat reproduksi yang berkualitas, bernilai tinggi yang diimpor, yang berdampak pada kenaikan biaya impor dalam proses produksi dan mempengaruhi area harga internal.

Perubahan rasio Bank Indonesia tentu saja berpengaruh terhadap tingkat suku bunga perusahaan perbankan, baik tingkat suku bunga simpanan, maupun tingkat suku bunga pinjaman. 
Apabila Bank Indonesia menerapkan kebijakan moneter ekspansif, dengan menurunkan tingkat suku bunga, maka suku bunga perbankan pun akan mengalami penurunan. Saat tingkat suku bunga bank turun, maka otomatis suku bunga pinjaman bank akan turun, hal ini akan meningkatkan permintaan kredit, baik kredit usaha maupun kredit rumah tangga. Tingkat suku bunga pinjaman yang rendah juga akan menarik investor untuk menanamkan modalnya karena biaya modal mengalami penurunan. Geliat usaha dan kegiatan ekonomi tumbuh pesat, hal ini dapat menurunkan tingkat inflasi (Bank Indonesia, 2013).

Sementara itu, jika Bank Indonesia mengeluarkan kebijakan berupa peningkatan suku bunga, maka suku bunga tabungan akan naik, sehingga orang-orang kehilangan minat untuk mengajukan kredit, dengan demikian permohonan kredit, baik kredit bisnis maupun individu akan mengalami penurunan, hal ini dikarenakan nasabah lebih memilih menabung daripada meminjam. Dengan menyimpan uang di bank, tentu pemilik dana akan memperoleh bunga, saat tingkat suku bunga tinggi, hal ini tentu menguntungkan.

Peningkatan dana beredar Dalam masyarakat, inflasi yang tinggi dan pertumbuhan dana abadi yang rendah menyebabkan inflasi yang tinggi. Kita dapat menyimpulkan bahwa hubungan antara pembiayaan dan inflasi adalah positif dan, jika meningkat, positif. Dalam pembiayaan, inflasi meningkat. deflasioner.

Sesuai apa yang telah dijabarkan oleh para ahli ekonomi dan perbankan, perekonomian akan tumbuh dengan baik jika berada pada tingkat harga umum, baik itu harga barang maupun jasa. Sebab tingkat inflasi rendah, harga stabil dan geliat pertumbuhan usaha ekonomi dapat berkembang sebagaimana mestinya. Pada dasarnya, inflasi digolongkan menjadi dua kategori, yaitu inflasi yang didorong oleh permintaan dan inflasi yang ditekan oleh biaya. Untuk memprediksi perubahan inflasi yang disebabkan oleh penawaran dan permintaan produk manufaktur, otoritas keuangan membuat kerangka kebijakan fiskal atau inflasi.

Target Framework (ITF) dengan menetapkan suku bunga. Inflasi dipengaruhi oleh beberapa hal, antara lain tingkat suku bunga pada berbagai produk perbankan seperti tabungan, kredit dan deposito. Tingkat suku bunga pada tabungan, kredit dan deposito tersebut akan mempengaruhi jumlah uang yang beredar. 
Penetapan kebijakan untuk menekan tingkat suku bunga pada ketiganya diharapkan akan berpengaruh pada tingkat inflasi yang akan menjadi rendah dan stabil, jika bank sentral dan bank Indonesia meningkatkan jumlah uang beredar untuk mendorong kegiatan ekonomi dan menjaga pertumbuhan ekonomi pada tingkat yang rendah. Selain tingkat inflasi, Tingkat suku bunga untuk penentuan suku bunga Bank Indonesia.

Perubahan jumlah uang yang beredar di masyarakat berpengaruh secara tidak langsung terhadap jalannya pertumbuhan ekonomi. Sementara itu, seperti telah disebutkan sebelumnya bahwa perubahan jumlah uang yang beredar sangat dipengaruhi oleh kebijakan Bank Indonesia dalam menaikkan dan menurunkan tingkat suku bunga untuk mengontrol terjadinya inflasi. Selain perubahan tingkat suku bunga dan perubahan jumlah uang yang beredar, inflasi juga dapat disebabkan oleh over biaya produksi. Biaya produksi yang tinggi menyebabkan harga barang menjadi tinggi. Hal ini tentu akan mempengaruhi minat konsumen untuk membeli suatu barang, maka munculah celah bagi produk impor untuk mengambil pasar.

Ini berarti bahwa pabrikan menghabiskan lebih banyak uang dalam hal ini. Anda dapat menggunakan dolar AS sebagai instrumen perdagangan untuk mengubahnya menjadi barang dan jasa. Hal ini menunjukkan bahwa ketika permintaan dolar meningkat, nilai rupee menurun. Dengan kata lain, rupee terdepresiasi terhadap dolar AS (Dealer membeli rupee / harga dolar lebih tinggi dari rupee), yang mempengaruhi tingkat harga.

\section{Tujuan Penelitian}

Berdasarkan pemaparan latar belakang permasalahan yang menjadi pokok penelitian tersebut, maka dalam penelitian ini peneliti bermaksud menganalisis pengaruh tingkat kurs, perubahan suku bunga Bank Indonesia serta jumlah uang yang beredar terhadap tingkat inflasi yang terjadi di Indonesia.

\section{TINJAUAN PUSTAKA}

\section{Tingkat Kurs Rp/Us Dollar}

Nilai tukar adalah nilai mata uang suatu negara dan diukur dalam mata uang negara lain. Survei ini menggunakan nilai tukar riil. Ini berarti harga relatif (hampir sama atau terkait) dari dua item. Penelitian ini menggunakan nilai tukar sementara yang ditetapkan oleh BI. Kurs tengah adalah hasil nilai tukar rupiah antara harga beli rupiah dengan harga jual rupiah terhadap dolar Amerika Serikat. 


\section{Tingkat Inflasi (INF)}

Inflasi adalah kenaikan harga yang berlangsung secara terus menerus selama periode waktu tertentu. Inflasi dapat dianalisis dan diketahui nilainya melalui perhitungan inflasi dengan mengaplikasikan konsep Indeks Harga Konsumen (IHK). IHK diterbitkan oleh Badan Pusat Statistik (BPS) dan Bank Indonesia melalui laporan kebijakan moneternya. Inflasi perlu dianalisis secara teliti agar dapat ditentukan kebijakan yang tepat untuk mengurangi laju pergerakannya, sehingga pertumbuhan ekonomi di suatu negara tidak akan terganggu oleh pergerakan inflasi yang tidak terkontrol.

\section{Suku Bunga BI (BIR)}

Suku Bunga Bank Indonesia atau BI Rate (BIR) merupakan suku bunga acuan yang disusun dan ditetapkan oleh Bank Indonesia dalam rangka menjalankan fungsinya sebagai Bank Sentral. Tujuan ditetapkannya suku bunga acuan ini adalah guna meningkatkan efektivitas terhadap jalannya kebijakan moneter secara menyeluruh.

\section{Jumlah Uang Beredar M2 (JUB)}

Uang diartikan sebagai aset yang dipergunakan dalam transaksi perekonomian. Uang beredar merupakan sejumlah uang yang dikeluarkan dan diedarkan oleh Bank sentral dan lembaga perbankan lainnya sebagai alat transaksi perekonomian. Uang Beredar terdiri dari tiga jenis uang, yaitu uang kartal dalam bentuk uang kertas dan uang logam, uang giral dalam bentuk surat-surat berharga, dan uang kuasi dalam bentuk deposito berjangka dan tabungan. Pengertian uang beredar dibagi menjadi dua kategori, yaitu uang yang beredar dalam arti sempit dan jumlah yang yang beredar dalam arti luas. Uang Beredar dalam arti sempit adalah jumlah uang kartal dan uang giral, yang dikenal dengan istilah M1. Sementara itu uang beredar dalam arti luas adalah penjumlahan dari uang beredar dalam arti sempit (M1) dengan uang kuasi.

\section{METODOLOGI PENELITIAN}

Penelitian menggunakan data sekunder jenis kuantitatif dimana pembatasan waktu penelitiannya adalah selama triwulan, pada periode 2012-2020. Konsep ini dipilih karena mempertimbangkan ketersediaan data dari lembaga yang berwenang untuk memberikan data. Secara umum penelitian ini menggunakan data deret waktu kuadratik, di mana penerapannya bergantung pada model penelitian yang digunakan. Sumber data yang peneliti peroleh adalah sumber data yang berasal dari beberapa lembaga yang berwenang melakukan pencatatan terhadap keuangan dan perbankan di Indonesia, yang meliputi Badan Pusat Statistik serta Badan Statistik Ekonomi dan Keuangan Indonesia. Untuk mengolah dan menganalisis data yang telah diperoleh dari sumber yang valid, maka peneliti menggunakan bentuk metode analisis yang 
disebut analisis error correction model (ECM). ECM dipilih karena beberapa alasan antara lain:

1. Menurut Insukindro (1993), ECM mampu menganalisis data yang tidak stasioner secara urutan waktu. Data seperti ini akan menghasilkan bentuk regresi linier lancung. Adapun yang dimaksud dengan regresi linier lancung (spurious regression) adalah jika nilai R2 pada perhitungan dengan sistem regresi linier memiliki nilai yang lebih tinggi daripada nilai Durbin Watson. Hal ini akan menyebabkan timbulnya koefisien regresi yang tidak efisien. Data yang dihasilkan menjadi tidak sesuai dengan keadaan sebenarnya, yang berdampak pada nilai koefisien yang tidak tepat menempati nilai mutlak.

2. Dalam analisis ECM juga digunakan uji stasioneritas. Uji ini digunakan untuk melihat indikasi adanya akar unit (unit root) di dalam suatu data time series. Untuk melakukan uji stasioner, diperlukan dua uji bantu lainnya yaitu uji uji Dickey-Fuller (DF) dan uji Augmented DickeyFuller (ADF).

3. Menurut Granger (Gujarati, 2003), tes awal atau presets untuk mencegah timbulnya regresi lancung adalah dengan melakukan uji kointegrasi. Uji kointegrasi merupakan salah satu uji yang dilakukan untuk mengamati keseimbangan berbagai faktor ekonomi yang mempengaruhi sejumlah kegiatan ekonomi dalam jangka waktu yang panjang. Untuk mengamati apakah dalam suatu kegiatan ekonomi terdapat kointegrasi, maka dilakukan uji AG-ADF (Angle Granger- Granger Augmented Dickey Fuller), jika uji tersebut menunjukkan adanya error stasioner, maka terdeteksi adanya kointegrasi.

4. Persamaan tunggal merupakan persamaan linier atau persamaan garis lurus yang akan menunjukkan hubungan jangka panjang dan jangka pendek dari berbagai faktor ekonomi.

\section{PEMBAHASAN}

\section{Pengujian Akar-Akar Unit (Unit Root Test)}

Pengujian akar-akar unit dibutuhkan dalam analisis Error Correction Models untuk menunjukkan validnya data tersebut. Dengan demikian data dalam penelitian ini harus bersifat stasioner. Pengujian stasioneritas data dilakukan terhadap seluruh variabel data yang menggunakan Dickey Fuller dan Augmented Dicky Fuller Test, yang perhitungannya menggunakan software Eviews. Hasil pengujian dapat dilihat pada tabel dibawah ini: 
Tabel 4.1. Hasil pengujian akar-akar unit dengan menggunakan ADF

\begin{tabular}{|c|c|c|c|c|c|c|}
\hline $\begin{array}{r}\text { Var } \\
\text { iab } \\
\text { el }\end{array}$ & $\begin{array}{l}\text { Inter } \\
\text { cept }\end{array}$ & $\begin{array}{c}\text { Level } \\
\text { Trend } \\
\text { and } \\
\text { Interce } \\
\text { pt }\end{array}$ & $\begin{array}{l}\text { No } \\
\text { ne }\end{array}$ & $\begin{array}{c}\text { Interc } \\
\text { ept }\end{array}$ & $\begin{array}{c}\text { First } \\
\text { Differ } \\
\text { ence } \\
\text { Trend } \\
\text { and } \\
\text { Interc } \\
\text { ept }\end{array}$ & $\begin{array}{c}\text { Non } \\
\mathrm{e}\end{array}$ \\
\hline Inf & $\begin{array}{r}- \\
1.82\end{array}$ & -2.16 & $\begin{array}{c} \\
0.8 \\
8\end{array}$ & $\begin{array}{c}- \\
5.71 * \\
* *\end{array}$ & $\begin{array}{c}- \\
5.93 * \\
* *\end{array}$ & $\begin{array}{c}- \\
5.73 \\
* * *\end{array}$ \\
\hline Bir & 1.25 & -1.50 & $\begin{array}{c}- \\
0.9 \\
4\end{array}$ & $\begin{array}{c}- \\
5.08^{*} \\
* *\end{array}$ & $\begin{array}{c}- \\
5.76^{*} \\
* *\end{array}$ & $\begin{array}{c}- \\
4.84 \\
* * *\end{array}$ \\
\hline Jub & 0.18 & $\begin{array}{c}- \\
5.31^{* *} \\
*\end{array}$ & $\begin{array}{c}6.7 \\
9\end{array}$ & $\begin{array}{c}- \\
10.01 \\
* * *\end{array}$ & $\begin{array}{c}- \\
10.19 \\
* * *\end{array}$ & $\begin{array}{c}- \\
3.76 \\
* * *\end{array}$ \\
\hline $\begin{array}{c}\text { Kur } \\
\mathrm{s}\end{array}$ & 1.42 & -1.33 & $\begin{array}{c}0.3 \\
9\end{array}$ & ${ }^{-}$ & $\begin{array}{c}- \\
3.32 * \\
*\end{array}$ & $\begin{array}{c}- \\
3.37 \\
* * *\end{array}$ \\
\hline
\end{tabular}

Sumber: Data diolah

Note :

*** : Nilai signifikan pada tingkat signifikansi 0,01

** : Nilai signifikan pada tingkat signifikansi 0.05

* Nilai signifikan pada tingkat signifikansi 0.10

Spesifikasi pada model ECM yang dipakai dengan berdasarkan pada perhitungan yang tepat guna mencari korelasi antara dua variabel yaitu variabel independen dan variabel dependen, persamaan korelasi tersebut bersifat mutlak dan tidak dapat ditolak sebab telah melalui perhitungan yang detail dengan memperhatikan berbagai aspek variabel. Berdasarkan hasil uji regresi EC dapat dilihat bahwa koefisien regresi memiliki pengaruh yang signifikan terhadap terjadinya inflasi. Yaitu pada tiga tingkatan yang meliputi $0,01,0,05$ dan 0,10. Tanda negatif menunjukkan bahwa pada koefisien HCT terjadi inflasi yang seimbang. Tanda negatif mengindikasikan pada akan terjadi penurunan inflasi pada periode berikutnya. 


\section{Koefisien Regresi dalam Jangka Pendek dan Jangka Panjang}

\begin{tabular}{crc}
\hline Variabel & $\begin{array}{c}\text { Koefisien } \\
\text { Jangka } \\
\text { Pendek }\end{array}$ & $\begin{array}{c}\text { Koefisien } \\
\text { Jangka } \\
\text { Panjang }\end{array}$ \\
\hline dBir & 2.89 & \\
Dl Hub & -3.66 & \\
dlnkurs & 3.68 & \\
ECT & -0.57 & \\
C & -106.82 & -108.35 \\
Bir & & 2.57 \\
lnjub & & 6.21 \\
lnkurs & & 0.42
\end{tabular}

Sumber: Data diolah

Dibawah ini akan dijelaskan penjabaran dari hasil perhitungan koefisien regresi pada variabel-variabel pada model ECM yang digunakan dalam menganalisis sekumpulan data:

\section{Pengaruh nilai Kurs terhadap tingkat inflasi di Indonesia}

Pada jangka pendek perubahan nilai Kurs memiliki nilai positif terhadap inflasi di Indonesia dan tidak berpengaruh secara signifikan terhadap inflasi karena nilai uji koefisien regresinya sebesar $3.68 \%$ lebih dari tingkat signifikansi yang sudah ditentukan sebelumnya. Ini menunjukan bahwa teori yang digunakan sudah sesuai yaitu bahwa jika tingkat kurs mengalami peningkatan maka Inflasi di Indonesia juga akan mengalami peningkatan. Sedangkan hasil uji pada jangka panjang menunjukan bahwa Kurs memiliki pengaruh Dari serangkaian uji yang telah dilakukan pada berbagai variabel tingkat tertentu, terindikasi bahwa kurs memberikan pengaruh positif tetapi tidak signifikan terhadap tingkat inflasi di Indonesia. Tabel di atas menunjukkan bahwa pada kenaikan kurs sebesar $1 \%$, maka akan terjadi kenaikan inflasi sebesar 0,42\%. Di bawah ini akan dijelaskan secara lebih rinci mengenai hubungan hipotesis penelitian dengan tingkat Inflasi di Indonesia yang menjadi objek penelitian sebelumnya, yaitu sebagai berikut:

\section{Analisis Adanya Pengaruh Perubahan BI Rate terhadap Tinggi Rendahnya Inflasi yang Terjadi di Indonesia}

Dalam penelitian ini terdapat beberapa variabel yang terlibat, antara lain variabel independen (variabel bebas) dan variabel dependen (variabel terikat). Variabel independen berupa perubahan BI rate sementara variabel dependen adalah tinggi rendahnya inflasi yang terjadi di Indonesia. 
Suku bunga BI dan BI Rate adalah ragam suku bunga yang dijadikan acuan oleh bank serta lembaga keuangan lain untuk menetapkan suku bunga pada tabungan, depostio, dan kredit. Dari penelitian, dapat dilihat bahwa suku bunga pada BI Rate memberikan pengaruh yang positif dan signifikan terhadap tinggi rendahnya inflasi yang terjadi di Indonesia pada jangka pendek selama periode tertentu.

Hal ini disebabkan karena pada periode tersebut pemerintah melakukan peningkatan harga barang produksi baik itu berupa benda ataupun jasa hal ini mengakibatkan terjadinya tekanan pada tingkat inflasi dengan demikian tujuan pemerintah menurunkan tingkat inflasi tidak dapat dilaksanakan. Hasil ini juga menunjukan bahwa teori yang ada tidak sesuai dengan hasil penelitian yang sudah dilakukan. Sedangkan hasil penelitian pada jangka panjang Suku bunga BI atau BI Rate mempunyai pengaruh positif dan signifikan terhadap tingkat inflasi di indonesia.

Hasil penelitian ini menunjukan bahwa tidak sesuai dengan dasar teori yang digunakan dan tidak sesuai dengan hipotesis bahwa jika semakin tinggi Suku bunga BI, maka tingkat inflasi di Indonesia akan mengalami penurunan. Dapat disimpulkan bahwa tinggi rendahnya tingkat Inflasi dipengaruhi oleh tinggi rendahnya tingkat suku bunga BI yang ditetapkan.

Hasil penelitian ini juga tidak sesuai dengan penelitian yang dilakukan oleh endri dalam penelitiannya menjelaskan bahwa tingkat kur memiliki pengaruh yang signifikan dan positif terhadap tingkat inflasi di Indonesia. Hasil temuan dalam penelitian ini diperkuat dengan fakta dan data yang ada bahwa jumlah uang yang beredar dari tahun 2017 sampai dengan tahun 2020 mengalami penurunan yang mengakibatkan peningkatan tingkat inflasi.

\section{Analisis Adanya Pengaruh Perubahan Jumlah Uang Beredar (JUB) terhadap Tinggi Rendahnya Inflasi yang terjadi di Indonesia}

Jumlah Uang Beredar (JUB) merupakan salah satu variabel independen dalam penelitian ini. Penelitian ini juga berusaha menggambarkan perubahan JUB terhadap tinggi rendahnya tingkat Inflasi di Indonesia. JUB dapat memengaruhi laju inflasi sebab tidak dapat dipungkiri bahwa Jumlah Uang Beredar, baik itu berbentuk M1 maupun M2, mempunyai likuiditas yang tinggi dan mempengaruhi kegiatan perekonomian khususnya perekonomian makro atau perekonomian nasional. 
Berdasarkan penelitian, diperoleh sejumlah data yang menunjukkan bahwa JUB memiliki pengaruh negatif dan tidak signifikan terhadap perubahan tingkat inflasi di Indonesia jika dilihat dalam jangka pendek. Tetapi apabila diamati pada jangka panjang, ternyata Jumlah Uang beredar memiliki pengaruh yang positif dan signifikan terhadap perubahan tingkat inflasi yang terjadi di Indonesia.

Hal ini ternyata sejalan dengan teori dan hipotesis yang telah dirumuskan bahwa, jika Jumlah Uang Beredar (JUB) di masyarakat tinggi, maka akan terjadi kenaikan inflasi di Indonesia. Jadi, dapat dijelaskan bahwa, semakin tinggi jumlah uang yang beredar di masyarakat maka inflasi akan menjadi semakin tinggi, begitu pula sebaliknya.

Dengan kata lain, tinggi maupun rendahnya inflasi di Indonesia, salah satunya juga disebabkan oleh besar kecilnya Jumlah uang yang beredar (JUB) di masyarakat yang diedarkan oleh Bank sentral. Ternyata, hasil penelitian dan kesimpulan ini sejalan dengan penelitian sebelumnya yang dilakukan oleh Adrian Sutawijaya pada tahun 2012.

Adrian Sutawijaya menerangkan bahwa terdapat korelasi yang positif dan signifikan antara Jumlah Uang Beredar (JUB) dengan tinggi rendahnya inflasi yang terjadi di Indonesia. Dari penelitian, dapat disebutkan bahwa pada tahun 2017 hingga tahun 2020 jumlah uang yang beredar di masyarakat terus mengalami penurunan, dan ternyata sejalan dengan hal tersebut, bank sentral mencatat bahwa inflasi juga mengalami penurunan sehingga tingkat harga barang dan jasa di masyarakat menjadi relatif stabil.

\section{Analisis terhadap Adanya Pengaruh Perubahan Tingkat Kurs terhadap Tinggi Rendahnya Inflasi yang terjadi di Indonesia}

Tingkat kurs mata uang, seperti halnya dengan BI rate dan JUB juga merupakan variabel independen yang mempengaruhi tinggi rendahnya inflasi yang berperan sebagai variabel dependen pada penelitian ini. Adapun yang dimaksud dengan kurs adalah tingkat harga atau besarnya nilai tukar mata mata uang yang beredar di suatu negara terhadap nilai mata uang lain.

Berdasarkan analisis terhadap hasil penelitian yang telah peneliti lakukan, dapat dijelaskan bahwa pada jangka pendek, kurs memiliki pengaruh yang positif terhadap tingkat inflasi, tetapi pengaruhnya tidak signifikan terhadap tingkat Inflasi yang terjadi di Indonesia. 
Sejalan dengan analisis pada jangka pendek, pada jangka panjang, tingkat kurs juga memberikan pengaruh positif tetapi tidak signifikan terhadap perubahan inflasi di Indonesia. Hal ini sejalan dengan teori dasar dan hipotesis yang telah dikemukakan sebelumnya bahwa jika tingkat kurs suatu mata uang terhadap mata uang asing mengalami peningkatan, maka secara otomatis tingkat inflasi di suatu negara juga akan semakin tinggi, begitu juga sebaliknya. Hal tersebut pun ternyata berlaku untuk tinggi rendahnya inflasi di Indonesia.

\section{Pengaruh perubahan Bir terhadap perubahan tingkat inflasi di Indonesia}

Berdasarkan hasil perhitungan yang telah dilakukan, diketahui bahwa terjadi perubahan persentase nilai BIR pada jangka pendek atau disebut DBIR. BIR mempunyai hubungan yang positif dan signifikan terhadap tinggi rendahnya inflasi yang terjadi di Indonesia. Secara teoritis, BIR dikatakan bahwa nilai BIR berbanding terbalik dengan perubahan tinggi rendahnya inflasi. Bila nilai BIR tinggi, maka inflasi akan menurun. Padahal berdasarkan penelitian, dapat dinyatakan bahwa nilai BIR berbanding lurus dengan perubahan inflasi.

Setiap kenaikan BIR sebesar satu persen, maka inflasi akan mengalami kenaikan sebesar 2,89 persen. Sejalan dengan hal tersebut, pada jangka panjang, BIR juga memberikan pengaruh yang positif dan signifikan. Setiap kenaikan nilai BIR sebesar satu persen, maka inflasi akan mengalami kenaikan sebesar 2,56 persen. Hal ini juga tidak sesuai dengan hipotesis awal yang telah dirumuskan maupun pada beberapa penelitian yang telah dilakukan sebelumnya.

\section{Pengaruh perubahan Jub terhadap perubahan tingkat inflasi di Indonesia}

JUB atau jumlah uang yang beredar juga tergolong sebagai variabel independen yang secara hipotesis akan memberikan pengaruh terhadap naik atau turunnya nilai inflasi yang terjadi di Indonesia. Nilai JUB jangka pendek atau dikenal dengan istilah Dlm hUB tercatat memiliki hubungan yang negatif dan tidak signifikan terhadap tinggi rendahnya inflasi. Hal ini tentu tidak sesuai dengan teori dan hipotesis yang dirumuskan, atau dengan kata lain hipotesis ditolak. 
Sebab pada kenaikan JUB jangka pendek, nilai inflasi tidak mengalami perubahan baik naik atau turun pada angka $-3,66$ persen. Sementara itu, bertolak belakang dengan nilai JUB jangka pendek, pada pengamatan jangka panjang diperoleh fakta bahwa nilai JUB memiliki pengaruh yang positif dan signifikan terhadap perubahan nilai inflasi. Berdasarkan pengamatan diperoleh hasil bahwa setiap kenaikan JUB sebesar 1 persen, maka inflasi akan mengalami kenaikan sebesar 6,21 persen. Hal ini berarti hipotesis diterima dan hasil pengamatan sejalan dengan teori yang telah ada.

\section{KESIMPULAN DAN SARAN}

\section{Kesimpulan}

Berdasarkan pengamatan serta analisis yang telah dilakukan terhadap sejumlah data dan fakta yang ditemukan di lapangan, maka peneliti dapat menyimpulkan beberapa hal antara lain:

1. Variabel tingkat kurs di Indonesia memiliki nilai positif terhadap inflasi serta tidak signifikan terhadap inflasi. Hal ini menunjukan bahwa nilai kurs rupiah terhadap nilai tukar Us Dollar mengalami kenaikan. Untuk variabel suku bunga bank Indonesia memiliki pengaruh yang positif dan signifikan terhadap tingkat inflasi di Indonesia ini menunjukkan bahwa hasil temuan yang ada tidak sesuai dengan teori yang sudah dikemukakan sebelumnya bahwa jika nilai Suku bunga BI mengalami peningkatan maka tingkat inflasi akan mengalami penurunan. Sedangkan pada variabel Jumlah uang yang beredar memiliki pengaruh yang negatif serta tidak berpengaruh secara signifikan terhadap Inflasi.

2. Untuk pengujian secara keseluruhan menunjukkan bahwa semua variabel memiliki pengaruh yang positif, hal ini dapat dilihat secara menyeluruh dan terutama pada jangka panjang. Pada jangka panjang seluruh variabel independen, baik itu tingkat kurs, suku bunga Bank Indonesia (BI Rate), dan jumlah uang yang beredar (JUB) memberikan pengaruh yang positif dan signifikan terhadap pertumbuhan inflasi yang terjadi di Indonesia. 


\section{DAFTAR PUSTAKA}

Badan Pusat Statistik. Statistik Indonesia, Berbagai edisi, Jakarta

Bank Indonesia .Laporan Perekonomian Indonesia, Berbagai edisi. Jakarta Bank Indonesia. Laporan Kebijakan Moneter, Berbagai edisi. Jakarta

Bank Indonesia. Statistik Ekonomi Keuangan Indonesia, Berbagai edisi, Jakarta Bank Indonesia. 2020. :http://www.bi.go.id/web/id/moneter/Transmisi+Kebijakan moneter.

Dornbusch, Rudiger, dan Fischer, Stanley. 1998. Macroeconomics: Fourth Edition. Singapore: McGraw-Hill Publications.

Endri.2008. Analisis faktor-faktor yang mempengaruhi inflasi di Indonesia tahun 1997-2005.

Frederic S.Mishkin. 2009. The Economics Of Money, Banking And Financial Market. Edisi ke-8. Penerbit: Salemba Empat.

Gujarati, Damodar, 2003. Basic Econometrics, Third Edition, Mc. Graw-Hill, International Editions, New York.

Insukindro.1993. Ekonomi Uang dan Bank. Yogyakarta : BP-FE Insukindro.1987. Pengantar Ekonomi Moneter, Yogyakarta : BP-FE

Mamik Wahjuanto. 2010. Beberapa Faktor Yang Mempengaruhi Laju Inflasi. Nopirin. 2010. Ekonomi Moneter II. Yogyakarta : BP-FE.

Nuri Anggraini. 2012. Analisis Pendapatan Nasional,Tingkat Suku Bunga SBI Dan Giro Wajib minimum Terhadap Jumlah Uang Beredar di Indonesia. 2012.

Prayitno dkk. Faktor-Faktor Yang Berpengaruh Terhadap Jumlah Uang Beredar di Indonesia Sebelum dan Sesudah Krisis: Sebuah Analisis Ekonometrika Jurnal Manajemen \& Kewirausahaan Vol. 4, No. 1, Maret 2002.

Samuelson, Paul A. dan Nordhaus, William D. 1995. Ilmu Makroekonomi. Jakarta: PT. Media Global Edukasi. 1995.

Warijiyo perry, 2003. Kebijakan Moneter di Indonesia. PPSK Jakarta. 